\title{
The Exploration of Historical Blocks' Protection and Renovation Based on the Theory of City Image
}

\author{
Hui Yu, Shubei Hou, Liang Lang \\ School of Architecture and Fine Art, Dalian University of Technology, Dalian, China \\ Email:18604081007@163.com,2445317967@qq.com, langbright621@dlut.edu.cn
}

How to cite this paper: Yu, H., Hou, S. B., \& Lang, L. (2018). The Exploration of Historical Blocks' Protection and Renovation Based on the Theory of City Image. Current Urban Studies, 6, 425-432.

https://doi.org/10.4236/cus.2018.63023

Received: August 12, 2018

Accepted: September 25, 2018

Published: September 28, 2018

Copyright (c) 2018 by authors and Scientific Research Publishing Inc. This work is licensed under the Creative Commons Attribution International License (CC BY 4.0).

http://creativecommons.org/licenses/by/4.0/

\begin{abstract}
Based on the theory of "the image of the city" proposed by Kevin Lynch, the article will discuss the protection and renovation of historic districts from five aspects: road, boundary, nodes, landmarks and region. And in this article, we will analyse three historic districts: Nanluogu Alley in Beijing, Guangsheng Temple in Yixian, Dongguan Street in Dalian. The purpose of this discussion is to explore how to improve the status of historic district in the city.
\end{abstract}

\section{Keywords}

The Image of the City, City Structural Elements, Historic District, Protection, Renovation

\section{Introduction}

As urban construction developing fast, historical block plays a special role in urban environment texture. Some urban areas' governments take positive attitudes to protect and renew historical blocks. However historical blocks in many areas of China have been ignored, which makes them incompatible with the local environment and become scar of the city, even slow down the construction and development of the city.

Therefore, the reasonable protection and renewal of historical districts is a permanent problem that cannot be ignored in the process of urban construction. Based on preserving original architectural features, we explore the potential development space of blocks, integrate it into surrounding environment by using certain methods, and injecting new vitality into the city. Only by this way can we protect and develop historical blocks. 
In this article, we will discuss the protection and renovation of historic districts based on the theory of "the image of the city" proposed by Kevin Lynch (1960). And we will analyse three historic districts around this theory-the historic districts are Nanluogu Alley in Beijing, Guangsheng Temple in Yixian, and Dongguan Street in Dalian-so as to improve the status of historic district in the city.

\section{The Introduction of Urban Image Theory}

The theory of urban image was proposed by Kevin Lynch (1960). He wrote the famous book named the Image of City, which is the milestone of urban design history. Based on urban public intention, he extracted five elements from the urban environmental texture. They are road, boundary, region, node and landmark. And then use this concept to cognize and explore the urban structure.

The theory of urban image is used to analyze the structural features of urban integrity. And it is the theoretical origin of urban planning and design. It also works to introduce urban image theory into the construction and renovation of block by He \& Deng (2014). When this theory used on the study of historical blocks' protection and renovation, it can provide a more systematic and clear analysis idea to make the protection and renovation more detailed and profound.

\section{The Definition of Urban Structural Elements in Historical Blocks}

The range of historical blocks is much smaller than that of cities, so we take group block instead of districts to analyze in this article. We will analyze the role of paths, edges, node, landmarks and group blocks in the historical block in Liu (2017).

Generally speaking, as linear elements, paths are the channels along which the observer moves. They may be streets, walkways, transit lines, canals, railroads Lynch (1960). Compared with the historical buildings in the block, streets are more open and changeable. In the process of protection and reconstruction of historical blocks, we can use specific design techniques to attract and gather people, and energizing the surrounding environment.

Edges are the linear elements not used or considered as paths by the observer. They are the boundaries between two phases. They may be shores, railroad cuts, edges of development, and walls in Kevin Lynch "The Image of City". Among modern urban environment, it plays the role of connection and communication with the surrounding environment. In the reconstruction of the surrounding historical block, it is necessary to use edges to define the historical block unit and integrate it into the urban environment.

Nodes are points, the strategic spots in a city into which an observer can enter. It usually refers to a transportation hub or a gathering point such as a square in Kevin Lynch "The Image of City". In historical blocks, the node is the gathering center of the crowd and is an important carrier of the public activities. The 
nodes are usually located at the corners of streets, it will be temples, old wells or other carriers to reflect their role in the block. In the design of the transformation, we can use some methods to innovate and activate the function of node space, so that it can be more inclusive and attractive.

Landmarks are another type of point-reference, but in this case the observer does not enter within them, they are external. In the historical district, landmarks have the function of strong identifiability and spiritual leadership. And they reflect the characteristics of the historic district. In the historical districts, landmarks may be towers, ancient trees and other forms exist. When it is protected and activated, it can be linked with the node space and street space to invigorate the entire historic block. For example, build a square around the landmark or develop an ancient alley leading to a landmark.

A region refers to a segment of city which has a large scale, and it usually has common characteristics and continuous theme in Kevin Lynch "The Image of City". This paper will analyze the status of the group block in place of the region. A group block refers to an area formed by a group of buildings with similar functional and spatial layout. In the protection and reconstruction of historical blocks, the key issue is to divide the same building style into groups and organize the layout of the road.

In a historical block, the five elements play their respective roles, and they combine and influence each other to form the basic face of the block. Therefore, reasonable design and planning and let the various elements interact with each other is the key issue for the protection and renovation of historical blocks.

\section{Analysis of Protection and Activation of Historical Blocks Based on Urban Image Theory}

\subsection{Integration and Weaving-Renovation of Dalian Dongguan Street}

Dalian Dongguan Street was built around 1920. The middle of the block is divided into two parts by Changjiang Road. It is mainly based on residential functions, and has many life service facilities such as hospital, theater and oil square.

Since Dongguan Street was built in the Japanese colonial period, it was influenced by the design of western cities. As shown in Figure 1: Its environmental texture is different from the traditional Chinese neighborhood system layout. It adopts the group layout of the enclosed courtyard in Wang (2015).

The main problems in Dongguan Street are as follows: 1) The district is out of touch with the surrounding environment and becomes a backward development area in the downtown area. 2) The distribution of buildings is disorderly. It results in chaos in the road system inside the block, which was showed in Yu, Sui, \& Li (2017).

The measures for protection and renovation of Dongguan District mainly include: 1) arrange the area and boundary of the building block, and weave the road system to make it more perfect and regular; 2) remove the messy and useless 


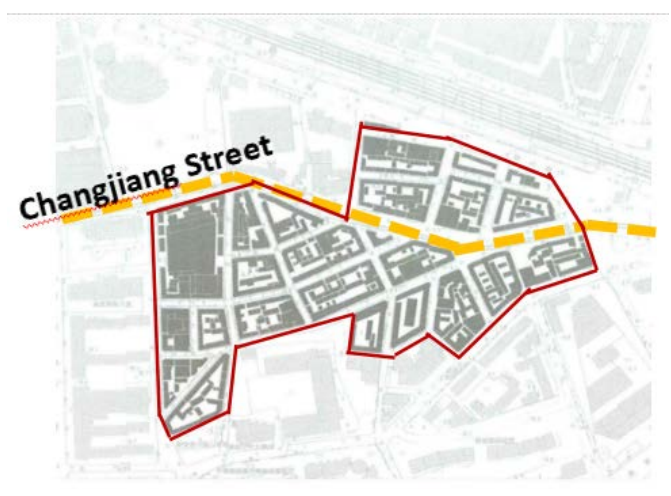

Figure 1. The map of Dongguan Street.

buildings, and appropriately increase the green cover in the block, and transform the negative space to the active space showed in Yu, Sui, \& Li (2017); 3) on this basis, use modern design elements and design techniques to renovate the street space. Such as, setting up street shops, rest benches, and outdoor tea garden, so as to revitalize the historic districts.

\subsection{Awakening and Leading-Renewal of Guangsheng Temple Historic District}

Yixian Guangsheng Temple was built in the Kaitai Period of the Liao Dynasty and it located in Yixian, Liaoning Province. The historical block radiates outward from the Guangsheng Tower (see Figure 2). The block is rectangular and its internal roads are relatively regular. The total area is about 110,000 square meters. The building in the block is in the form of a dome-style courtyard house. There are small supermarkets on both sides of the alleyway, and basic living service facilities such as car repair booths.

The Guangsheng Temple Historic District is located in the town. There is no potential and advantage that can make it develop into a tourist attraction like the Fengguo Temple. The local government's protection measures are relatively negative and backward. The block has become a desolate zone in the county seat. Therefore, there are many problems in it that need to be solved: 1) $90 \%$ of the alleys in the block are dirt roads, and the roads only 3 meters wide. People and vehicles are mixed and dusty; 2) the environmental texture is extremely uneven. There are idle plots near the Guangsheng Temple Tower in the center of the block (as shown in Figure 2). The grass is crowded, and the courtyards in the alley are crowded and cluttered.

Measures for the protection and renovation of the Guangshengsi Historic District include as follows: 1) renovate the roads in the block and lay blue bricks on the road; put benches, street lamps, pools, greenery, etc. Activate residential houses along the street and transform them into residential units that combine business and residence. And impose time limit restrictions on motor vehicles; 2) create a block node and combine it with the block landmark design: transform the negative zone into a residential activity square, and combine the tower to 


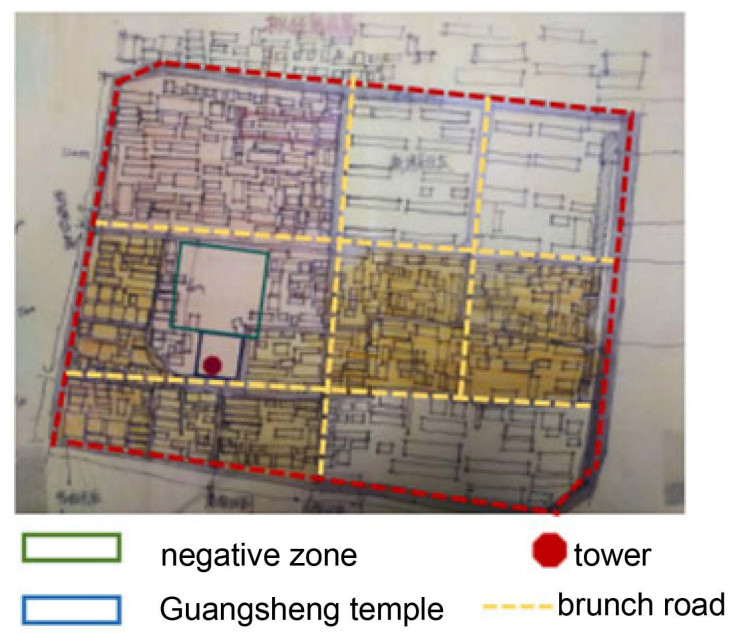

Figure 2. The map of Guangsheng Temple.

become the center of the activated block (as shown in Figure 3), so as to attract local residents; 3) regularize the layout of the courtyard to remove messy and useless buildings, and weave environmental texture by setting outdoor activity spaces and green plants.

\subsection{Linkage and Activation-Protection and Renovation of Nanluogu Alley}

Nanluogu alley is located on the east side of the central axis of Beijing's old city. It starts from Gulou East Street in the north, Shichahai in the west and Drum Tower in the northwest. It is a historical district with a strong Ming and Qing culture. There are many well-preserved traditional courtyard houses and small gardens. The entire historical block is a fish-bone layout, with 16 hutongs arranged symmetrically on the left and right sides by a cultural tourism leisure corridor connecting the north and the south (as shown in Figure 4). The overall structure of the trunk-branch-organization three-level block structure, the trunk represents Nanluogu alley, and the branch vein represents the 16 branches connected to the trunk. The organization refers to the different functional group blocks. The district is also interspersed with ancient gardens, such as the important node elements of celebrity ancestral halls in Dai \& Gai (2009).

The current problems in the historical block of Nanluoguxiang are mainly as follows: The branch road and main road does not form a continuous and complete road system, and the node elements such as gardens are not well designed with the road system. The utilization rate is low. The historic district was not fully activated.

The renovation and activation measures for the Nanluoguxiang Historic District are as follows: Protect the openness and richness of the main street, and extend the existing public life to the street reconstruction of the branch road, so that the main road and the branch road form a continuous organism. The environmental texture on both sides of the branch road is interspersed with node 


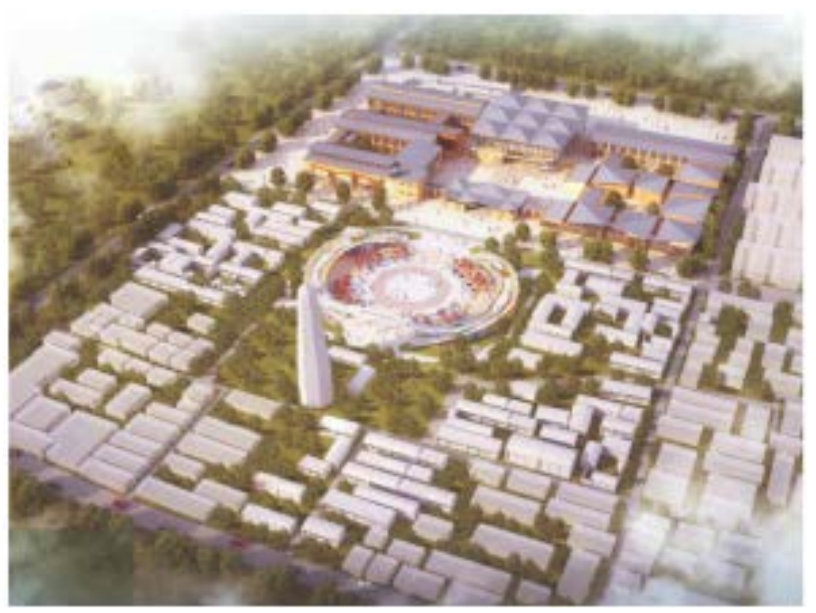

Figure 3. Renewal of space-build square.

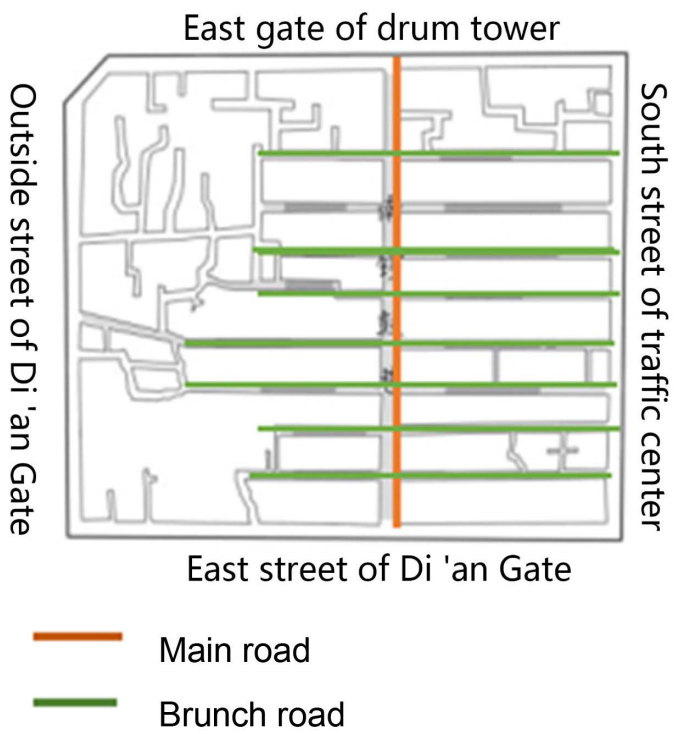

Figure 4. The map of Nanluogu Alley.

elements in the group block. There are handicrafts, garments, cotton workshops, private gardens and ancestral halls arranged as block nodes (as shown in Figure 5). The branch road can be activated by the following two aspects: 1) renovate the group block: redesigning the space and facade of the building along the street, forming a form of exhibition and sales, and guiding the tourists to the branch road; 2) improve the continuity design of the road so that it is well connected with the node elements of the block. Through the design of the tour streamline, the private gardens and the ancestral halls are woven together to form a linkage of the road-block-node three elements, and the historical blocks are fully activated.

\section{Conclusion}

The specific historical block carries the special historical memory of the place. It 


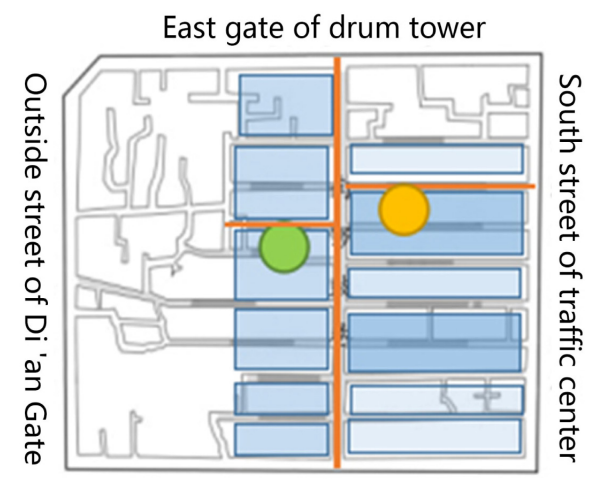

East street of Di 'an Gate

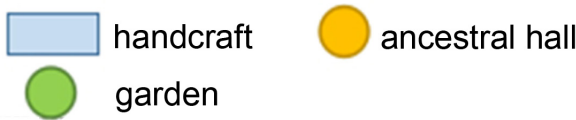

Figure 5. The map of node and blocks.

plays a non-negligible role in the city, and extends the city's image in the time dimension. In China, people's cognition and operation of how to renovate historical blocks is lack. This article starts from five major structural elements of paths, edges, nodes, landmarks and group blocks. We analyze the reconstruction methods of Dalian Dongguan Street, Yixian Guangsheng Temple, and Nanluogu Alley. Our aim is to provide reference and paving for the development of historical block protection work for different types of environmental textures in the future.

The protection and renovation of historical blocks is a sensitive issue in urban design. It is closely related to the development of the city. It is urgent for us to carry out in-depth exploration and practical solutions. Under the conditions of satisfying the basic functions of space, we should protect and transform historical blocks to satisfy people's spiritual needs as much as possible, so as to awaken the collective memory of the masses.

\section{Conflicts of Interest}

The authors declare no conflicts of interest regarding the publication of this paper.

\section{References}

Dai, L. L., \& Gai, S. J. (2009). Sustainable Regeneration of Beijing Nanluoguxiang Historic District. Huazhong Architecture, 27, 173-177. http://kns.cnki.net/KCMS/detail/detail.aspx?dbcode=CJFQ\&dbname=CJFD2009\&filena me=HZJZ200905045\&uid=WEEvREcwSlJHSldRa1FhdXNXa0hFbHQxY1A4L2ZjRnNY Z1FEVjRTSFdyOD0=\$9A4hF_YAuvQ5obgVAqNKPCYcEjKensW4IQMovwHtwkF4VY PoHbKxJw!!\&v=MTQxODIxTHV4WVM3RGgxVDNxVHJXTTFGckNVUkxLZmJ1Z G9GeUhoVTdyUExUZkJkTEc0SHRqTXFvOUJZWVI4ZVg=

He, Y., \& Deng, W. (2014). Research on the Prototype and Type of Building Texture in Historical Blocks. Urban Planning, 38, 57-62.

http://kns.cnki.net/KCMS/detail/detail.aspx?dbcode=CJFQ\&dbname=CJFD2014\&filen 
ame $=$ CSGH201408014\&uid $=$ WEEvREcwSlJHSldRa1FhdXNXa0hFbHQxY1A4L2ZjRn NYZ1FEVjRTSFdyOD0=\$9A4hF_YAuvQ5obgVAqNKPCYcEjKensW4IQMovwHtwk F4VYPoHbKxJw!!\&v=MzA0MDFyQ1VSTEtmYnVkb0Z5SGdVYjdJSmo3TVpyRzRIO VhNcDQ5RVlJUjhlWDFMdXhZUzdEaDFUM3FUcldNMUY=

Liu, B. M. (2017). From "Architectural Protection" to "Structural Protection"-A Further Analysis of the Space of Historical Blocks. 2017 Proceedings of the Annual Conference on Urban Planning in China, Dongguan, 18 November 2017. http://kns.cnki.net/KCMS/detail/detail.aspx?dbcode=CPFD\&dbname=CPFDLAST201 7\&filename=ZHCG201711009066\&uid=WEEvREcwSlJHSldRa1FhdXNXa0hFbHQxY1 A4L2ZjRnNYZ1FEVjRTSFdyOD0=\$9A4hF_YAuvQ5obgVAqNKPCYcEjKensW4IQM ovwHtwkF4VYPoHbKxJw!!\&v=MjE0NDBQeVhJYWJHNEg5Yk5ybzlGYmVzSkNoTkt 1aGRobmo5OFRuanFxeGRFZU1PVUtyaWZadTV2SHlqalU3Yk5LVjRT

Lynch, K. (1960). The Image of City. The Third Chapter. Cambridge: The MIT Press.

Wang, W. (2015). Take Dongguan Street of Dalian as an Example to Discuss the Protection of Historical block. Shanxi Architecture, 41, 8-9.

http://kns.cnki.net/KCMS/detail/detail.aspx?dbcode=CJFQ\&dbname=CJFDLAST2016 \&filename=JZSX201536005\&uid=WEEvREcwSlJHSldRa1FhdXNXa0hFbHQxY1A4L2 ZjRnNYZ1FEVjRTSFdyOD0=\$9A4hF_YAuvQ5obgVAqNKPCYcEjKensW4IQMovw HtwkF4VYPoHbKxJw!!\&v=MTQ3NjhIOVRQcVk5RllZUjhlWDFMdXhZUzdEaDFU M3FUcldNMUZyQ1VSTEtmYnVkb0Z5SGdXN3pJTHpmWWRyRzQ=

Yu, H., Sui, X. J., \& Li, S. (2017). Continuation and Reconstruction of Conservation and Renewal of Three Types of Spatial Historic Districts-Taking Dalian Historic Districts for Example. Architecture and Culture, 8, 47-48.

http://kns.cnki.net/KCMS/detail/detail.aspx?dbcode=CJFQ\&dbname=CJFDLAST2017 \&filename $=J Z Y W 201708015$ \&uid $=$ WEEvREcwSlJHSldRa1FhdXNXa0hFbHQxY1A4L2 ZjRnNYZ1FEVjRTSFdyOD0=\$9A4hF_YAuvQ5obgVAqNKPCYcEjKensW4IQMovw HtwkF4VYPoHbKxJw!!\&v=MDcwNDV4WVM3RGgxVDNxVHJXTTFGckNVUkxLZ mJ1ZG9GeUhoVXJySkx6ZlN1Ykc0SDliTXA0OUVZWVI4ZVgxTHU= 